\title{
Wspomnienie o Profesorze Bohdanie Jałowieckim (1934-2020)
}

In Memoriam: Professor Bohdan Jałowiecki (1934-2020)

$\mathrm{Na}$ stronie internetowej Centrum Europejskich Studiów Regionalnych i Lokalnych UW (EUROREG) można znaleźć krótką, acz treściwą informację: „Autor ponad 300 publikacji, w tym 18 zwartych publikacji książkowych, redaktor kilkunastu wydawnictw zbiorowych. Ponad 20 prac opublikował za granicą w różnych językach. Główny dorobek w zakresie socjologii miasta oraz rozwoju regionalnego i lokalnego. (Index „h” = 34). [...] Wykładał gościnnie na Uniwersytecie Paryż I - Sorbona oraz na Uniwersytecie im. Paula Valéry’ego w Montpellier. W latach 1970-1974 brał udział w opracowaniu ogólnego planu

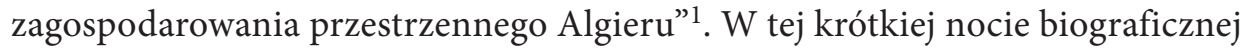
dla studentów o wykładowcy Profesorze Bohdanie Jałowieckim nie znalazła się wzmianka o Jego pracy w Instytucie Rozwoju Wsi i Rolnictwa PAN w latach 1981-1986, kiedy kierował Zakładem Socjologii Wsi. Chcę tu przypomnieć zainteresowania Bohdana problematyką wsi. Pracowałam z nim bowiem - nie opuszczając całkowicie IRWIR PAN - w EUROREG UW w latach 1997-2017. Zamieszczam tu kilka zdań o moim przyjacielu, któremu w żartach mówiłam, że jest niespełnionym socjologiem wsi.

Jego zainteresowania zagadnieniami związanymi z wsią pojawiły się $\mathrm{w}$ analizach wpływu industrializacji i urbanizacji na przemiany społeczności wiejskich $\mathrm{i}$ ich relacji $\mathrm{z}$ otoczeniem. Ten wątek pojawia się $\mathrm{w}$ latach 60 . i podejmowany jest do końca lat 80 . XX w., między chronologicznie pierwszą publikacją $Z$ badań nad procesem adaptacji i integracji społecznej na Dolnym Śląsku (1963) a książką Proces urbanizacji a relacje miasto-wieś (1987). Ostatnią „wiejską afiliacją" Jałowieckiego jest wstęp pt. Między miastem a wsią do książki Wieś jako

1 https://www.euroreg.uw.edu.pl/pl/byli-pracownicy,bohdan-jalowiecki (dostęp: 06.12.2021). 
przedmiot badań naukowych na początku XXI wieku (2011), której powstanie zainspirowały trzy publikacje pod Jego redakcją na temat miasta ${ }^{2}$.

W latach 60. XX w. przejawiane przez Jałowieckiego zainteresowanie tematyką wsi odnosiło się do badań nad industrializacją i urbanizacją kraju prowadzonych przez Komitet Badań Rejonów Uprzemysławianych PAN, z którego w 1971 r. powstał IRWIR PAN. Badania te realizowano głównie na Dolnym Śląsku. Był to szczególny region w kontekście badawczym, gdyż zachodzące tu procesy industrializacji i urbanizacji miały swoją specyfikę. „Polega ona na nawarstwieniu się jakby dwóch procesów. Oddzielenie ich oczywiście jest możliwe tylko na drodze abstrakcji [...]. Te dwie warstwy procesów to z jednej strony adaptacja i integracja ludności przybyłej z różnych stron Polski i wielu krajów Europy w latach bezpośrednio po wojnie, a z drugiej strony zjawiska społecznie związane z napływem dużej fali nowych przybyszy w związku z rozpoczętą industrializacją" (1967, s. 7). Synteza tych badań znajduje się w pracy Polkowice, przemiany społeczności lokalnej pod wplywem uprzemysłowienia (1967). W czasie prowadzonych badań była to wieś, która po II wojnie światowej straciła prawa miejskie. Jałowieckiego interesował tu zarówno proces ruralizacji, jak i reurbanizacji. O wyborze tej miejscowości jako przedmiotu badań zadecydował bowiem „fakt całkowitej niemal ruralizacji tego osiedla, posiadającego prawa miejskie od XIII wieku, w wyniku zasiedlenia go przez ludność w $85 \%$ pochodzenia wiejskiego, i to w znacznej mierze bardzo bliskich idealnemu typowi «społeczności ludowej», przez mieszkańców wsi Bukowiny oraz bieszczadzkich i sądeckich Łemków. Paradoksalny to fakt, że ludzie ci przybywający do Polkowic znaleźli się w mieście, przynajmniej $\mathrm{w}$ materialno-przestrzennym i administracyjnym sensie, a następnie, nie zmieniając miejsca zamieszkania, stali się mieszkańcami wsi nie tylko w administracyjnym, ale i demograficzno-społecznym znaczeniu" (1967, s. 7). Polkowice były szczególne nie tylko pod tym względem. Była to bowiem wieś, w której już na początku lat 60. ponad 2/3 ludności utrzymywało się z zajęć pozarolniczych.

W pochodzącym z 1966 r. artykule Proces urbanizacji wsi jako czynnik zmienności układu osadniczego - przygotowanym na podstawie badań w powiatach wrocławskim i opolskim - Jałowiecki proponuje śledzić wpływ urbanizacji na rodzinę, społeczności lokalne oraz region. Opisywanym przykładem jest powiat wrocławski i jego 150 miejscowości, które poprzez analizę statystyczną podzielono na typy, od najmniej do najbardziej zurbanizowanych. W efekcie wielostronnej analizy Jałowiecki dochodzi do wniosku, że pod wpływem urbanizacji zanikają społeczności lokalne,

2 Były to kolejno: Miasto jako przedmiot badań naukowych. Materiały z interdyscyplinarnej konferencji naukowej, Wisła, grudzień 1969, B. Jałowiecki (red.), Śląski Instytut Naukowy, Katowice 1971; Miasto jako przedmiot badań naukowych - refleksje po 10 latach, B. Jałowiecki (red.), seria: Górnośląskie Studia Socjologiczne, t. 15, Śląski Instytut Naukowy, Katowice 1982, a także Miasto jako przedmiot badań naukowych w początkach XXI wieku, B. Jałowiecki (red.), Wydawnictwo Naukowe Scholar, Warszawa 2008. 
a pojawiają się zbiorowości terytorialne - zróżnicowane i o specyficznym charakterze więzi - które stają się „strefą rozrzedzonych kontaktów społecznych” (Jałowiecki 1966, s. 106). Jałowieckiego interesują przede wszystkim wiejskie społeczności atypowe: niechłopskie, wsie robotnicze, pegeerowskie, których specyfikę ukazuje, zestawiając je z wsiami chłopskimi. Taki charakter mają dwie ważne rozprawy: Niektóre problemy odrębności struktury przestrzenno-społecznej osiedli PGR na przykładzie powiatu wrocławskiego (1966) oraz Społeczno-przestrzenna struktura wsi nierolniczych (1967). W sie niechłopskie (a więc atypowe) mają podobną do siebie strukturę, a zarazem odmienną od wsi chłopskich. Bardzo ciekawa jest pod tym względem typologia 157 wsi powiatu wrocławskiego $\mathrm{z}$ analizą przestrzeni tych jednostek, obejmująca przestrzenną część topograficzno-strukturalną oraz relacyjną, w tym np. analizę stereotypów. Do analizy przestrzeni międzyludzkiej Jałowiecki włączył także (prekursorsko) kategorię gender, której ówczesną palącą kwestią jest to, czy kobieta, zwłaszcza po zamążpójściu, powinna pracować zarobkowo. To zainteresowanie atypowymi zbiorowościami wiejskimi nie jest przypadkowe: było to programowe przeciwstawienie się panującemu w polskiej socjologii wsi chłopocentryzmowi i postrzeganiu wsi jako jednorodnej społecznie, „co czyni ją płaską, jednowymiarową” (1987, s. 94).

Rozbrat z problematyką wsi bierze Profesor Jałowiecki w książce Proces urbanizacji a relacje miasto-wieś (1987). Rozważa tu, na ile trafna - jako kategoria analizy - jest opozycja/kontinuum wieś-miasto, która nie jest ani kategorią uniwersalną, ani nie określa kierunku przekształcenia zbiorowości. Na zaawansowanym poziomie rozwoju ekonomicznego pojawiają się bowiem nowe zjawiska, takie jak powroty na wieś, ruralizacja miast czy koncepcja włączania wsi do społeczeństwa globalnego. Jałowiecki wskazuje też na możliwości analityczne innej kategorii: centrum-peryferie, której użyteczność zasadza się m.in. na istnieniu ścisłych związków między tymi dwiema formami - „centrum nie istnieje bez peryferii i na odwrót” (1987, s. 21). Wiele miejsca poświęca tu przeobrażeniom sieci osadniczej, dokonując przeglądu istniejących typologii. Zwraca także uwagę na nowe, jeszcze w owym czasie w Polsce incydentalne, zjawiska: rurbanizację oraz „drugie domy”, czyli przekształcanie się wsi z przestrzeni produkcyjnej w przestrzeń konsumpcji $\mathrm{w}$ dwojakim rozumieniu tego słowa - przestrzeń, gdzie odbywa się konsumpcja, oraz przestrzeń konsumowaną. Autor kończy postawieniem wielu pytań aktualnych do dziś, a dotyczących: zasadności utożsamiania wsi z rolnictwem, rolnikami; braku analiz ich wewnętrznego zróżnicowania; specyfiki i autonomii kultury chłopskiej/ ludowej/wiejskiej; charakteru kształtujących się stref pośrednich - „miastowsi”; wpływu wiejskości na społeczeństwo polskie.

Wspominam ten wiejski, mało znany wątek zainteresowań Bohdana, cenionego przede wszystkim za prace z zakresu socjologii miasta, socjologii przestrzeni, rozwoju regionalnego i lokalnego. Z uwagi na to, że wpływy miasta na wieś przybierają różne 
nowe formy (np. zjawisko gentryfikacji), które zmieniają wiejską przestrzeń, w pracach nie tylko socjologów z Instytutu Rozwoju Wsi i Rolnictwa PAN często można znaleźć odwołania do dorobku Jałowieckiego niezwiązanego z problematyką wsi.

Maria Halamska

\section{Bibliografia prac Bohdana Jałowieckiego dotyczących tematyki wsi}

\section{Książki}

1. (1967). Polkowice, przemiany społeczności lokalnej pod wpływem uprzemysłowienia. Wrocław i in.: Zakład Narodowy im. Ossolińskich - Wydawnictwo.

2. (1987). Proces urbanizacji a relacje miasto-wieś. Warszawa: Państwowe Wydawnictwo Naukowe.

\section{Artykuty i rozdziały}

3. (1963). Z badań nad procesem adaptacji i integracji społecznej na Dolnym Śląsku. Wieś Strzegomiany w pow. Wrocławskim. Śląski Kwartalnik Historyczny „Sobótka”, 18 (4), 472-498.

4. (1965). Struktura demograficzna i gospodarcza wsi Głogowice. Roczniki Etnografii Śląska, 31-64.

5. (1965). Proces urbanizacji wsi jako czynnik zmienności układu osadniczego. Roczniki Socjologii Wsi, 4, 91-109.

6. (1965). Niektóre problemy socjologiczne rejonów uprzemysławianych. Zeszyty Badań Rejonów Uprzemysławianych, 16, 264-313.

7. (1966). Niektóre problemy odrębności struktury przestrzenno-społecznej osiedli PGR na przykładzie powiatu wrocławskiego. Roczniki Socjologii Wsi, 5, 122-128.

8. (1967). Osadnictwo robotnicze jako czynnik urbanizacji wsi. Odra, 10, 21-26.

9. (1967). Problematyka osadnictwa robotniczego na wsi. Ruch Prawniczy, Ekonomiczny i Socjologiczny, 3, 261-273.

10. (1967). Społeczno-przestrzenna struktura wsi nierolniczych. Roczniki Socjologii Wsi, 7, 136-153.

11. (1971). Aspekty socjologiczne osadnictwa robotniczego na wsi. W: S. Golachowski, E. Goldzamt (red.). Problemy osadnictwa robotniczego na wsi (s. 217-224). Warszawa: Państwowe Wydawnictwo Naukowe.

12. (1971). Czynniki społeczne rozmieszczenia osadnictwa robotniczego na wsi. W: S. Golachowski, E. Goldzamt (red.). Problemy osadnictwa robotniczego na wsi (s. 90-104). Warszawa: Państwowe Wydawnictwo Naukowe.

13. (1972). Procesy urbanizacji wsi w rejonie Kędzierzyn-Koźle. Ziemia Kozielska, 2, 2-32.

14. (1983). Relacje miasto-wieś. Zarys problematyki teoretycznej. Wieś i Rolnictwo, 3, 19-26.

15. (2011). Wstęp. Między miastem a wsią. W: M. Halamska (red.). Wieś jako przedmiot badań naukowych na początku XXI wieku (s. 7-11). Warszawa: Wydawnictwo Naukowe Scholar. 